\title{
CREM Gene
}

National Cancer Institute

\section{Source}

National Cancer Institute. CREM Gene. NCI Thesaurus. Code C162403.

This gene plays a role in the regulation of cAMP response element (CRE)-dependent gene transcription. 